\title{
Myofibroblasts and S-100 protein positive cells in idiopathic pulmonary fibrosis and rheumatoid arthritis-associated interstitial pneumonia
}

\author{
T. Yoshinouchi", Y. Ohtsuki*, R. Ueda**, S. Sato**, N. Ueda ${ }^{+}$
}

\begin{abstract}
Myofibroblasts and S-100 protein positive cells in idiopathic pulmonary fibrosis and rheumatoid arthritis-associated interstitial pneumonia. T. Yoshinouchi, Y. Ohtsuki, R. Ueda, S. Sato, N. Ueda. C)ERS Journals Ltd 1999.

ABSTRACT: The aim of this study was to investigate whether idiopathic pulmonary fibrosis (IPF) can be distinguished from rheumatoid arthritis (RA)-associated interstitial pneumonia (RA-IP) by means of quantitatively assessing myofibroblasts and S100 protein positive dendritic cells.

Seven patients with IPF and twelve with RA, in whom the pathological findings were consistent with usual interstitial pneumonia (UIP) were studied. Antibodies to vimentin, $\alpha$-smooth muscle actin ( $\alpha$-SMA) and S-100 protein were used for immunohistochemical studies performed using the streptavidin/biotin/peroxidase complex method, applied to dewaxed sections from each case.

In fibrosis of RA-IP, appearance of both vimentin- and $\alpha$-SMA-positive cells, namely myofibroblasts, was widely observed, together with the pathological patterns of honeycombing, UIP and bronchiolitis obliterans-organizing pneumonia (BOOP). Fibrosis, in cases of chronic IPF, was found to be characterized mainly by vimentinpositive but $\alpha$-SMA-negative fibroblasts. Pulmonary tissues from RA-IP patients especially when associated with a BOOP pattern, contained many cells positive for S100 protein. However, such cells were generally hard to find in cases of IPF.

These findings suggests that idiopathic pulmonary fibrosis and rheumatoid arthritis-associated interstitial pneumonia can be differentiated from each other, to some extent, based on the appearance of myofibroblasts and the presence of S-100-positive dendritic cells.
\end{abstract}

Eur Respir J 1999; 14: 579-584.

Idiopathic pulmonary fibrosis (IPF) takes an aggressive course that begins with alveolitis and progresses to interstitial fibrosis [1]. In terms of pathology, this disease corresponds to usual interstitial pneumonia (UIP) [2-4]. The histological profile of rheumatoid arthritis (RA)-associated interstitial pneumonia (RA-IP) consists of various pathological findings, including UIP, bronchiolitis obliterans-organizing pneumonia (BOOP), lymphoid hyperplasia, diffuse alveolar damage, cellular interstitial pneumonia, and eosinophilic pneumonia [5]. However, the pathological features of both IPF and RA-IP are mostly those of UIP, and interstitial pneumonia of IPF and RA has been suggested to be the same pathological entity. Therefore decisive distinction between these two conditions is usually difficult.

Recently, classification of cryptogenic organizing pneumonia (COP) into type I and type II, according to differences in both degree of myofibrosis and nature of Masson bodies, was advocated and it was reported that type I, in particular, responds very well to steroids [6]. Therefore, the fibroblast of interstitial pneumonia may exhibit different patterns of positivity for antibodies to vimentin, $\alpha-$ smooth muscle actin ( $\alpha$-SMA) and desmin.

S-100 protein was discovered in bovine brain by MOORE [7] in 1965, and subsequently shown also to be

\author{
Dept of Internal Medicine, Gamagor \\ City Hospital, *The Second Dept of \\ Pathology, Kochi Medical School, ${ }^{* *}$ The \\ Second Dept of Internal Medicine, Nago- \\ ya City University Medical School, ${ }^{+}$Dept \\ of Internal Medicine, Ehime Prefectural \\ Central Hospital. \\ Correspondence: T. Yoshinouchi \\ The Second Dept of Internal Medicine \\ Nagoya City University Medical School \\ Mizuho-ku \\ Nagoya 467-8601 \\ Japan \\ Fax: 81528520849
}

Keywords: Idiopathic pulmonary fibrosis interstitial pneumonia

myofibroblast

rheumatoid arthritis

S-100 protein

Received: March 231998

Accepted after revision April 201999 distributed widely in various human tissues. Human lymphoreticular tissues, Langerhans' cells of the skin, interdigitating cells of lymph nodes and some suppressor/ cytotoxic $T$ cells are positive for $S-100$ protein $[8,9]$. In addition, the presence of S-100 protein-positive dendritic cells (S-100 DC) has been also reported in various kinds of carcinoma, including lung, in relation to the patients' prognosis [10]. These observations hence suggest that S100 DCs might be detected in pulmonary lesions, especially related to autoimmunity or an abnormal immune surveillance system including collagen vascular diseases.

The aim of this study, was to determine whether pulmonary lesions in IPF and RA-IP are different with regard to the pathological features of myofibrosis and the number and distribution of S-100 DCs by immunohistochemical staining.

\section{Material and methods}

The subjects were seven patients with IPF and 12 patients with RA-IP, in whom pathological evidence of UIP or its pattern, respectively, was obtained by open lung biopsy or autopsy (table 1). The 12 RA patients selected for the study fulfilled the criteria for "classical" or 
Table 1. - Clinical features of patients with idiopathic pulmonary fibrosis (IPF) and rheumatoid arthritis (RA)

\begin{tabular}{|c|c|c|c|c|c|c|c|}
\hline $\begin{array}{l}\text { Patient* } \\
\text { No. }\end{array}$ & $\begin{array}{l}\text { Age } \\
\text { yrs }\end{array}$ & Sex & Smoker & $\begin{array}{l}\text { Diagnostic } \\
\text { technique }\end{array}$ & $\begin{array}{l}\mathrm{LDH} \\
\mathrm{IU} \cdot \mathrm{L}^{-1}\end{array}$ & $\begin{array}{l}{\mathrm{Pa}, \mathrm{O}_{2}} \\
\mathrm{mmHg}\end{array}$ & $\begin{array}{l}\mathrm{VC} \\
\% \text { pred }\end{array}$ \\
\hline $1^{+}$ & 74 & $\mathrm{M}$ & + & A & 631 & 38.5 & - \\
\hline $2^{+}$ & 74 & $\mathrm{M}$ & + & A & 1156 & 56.6 & - \\
\hline 3 & 74 & M & - & OLB & 381 & 91.9 & 93.3 \\
\hline 4 & 73 & M & + & OLB & 253 & 78.9 & 84.9 \\
\hline 5 & 61 & M & + & OLB & 424 & 54.0 & 72.6 \\
\hline 6 & 76 & M & + & A & - & 59.9 & - \\
\hline 7 & 62 & $\mathrm{M}$ & - & OLB & 433 & 71.9 & 96.3 \\
\hline 8 & 89 & M & - & OLB & 695 & 47.7 & - \\
\hline 9 & 76 & M & + & A & 591 & 61.9 & - \\
\hline 10 & 64 & $\mathrm{~F}$ & - & A & 808 & 57.9 & - \\
\hline 11 & 64 & M & + & OLB & 715 & - & - \\
\hline 12 & 84 & F & - & A & 471 & 41.1 & - \\
\hline 13 & 56 & F & - & OLB & 346 & 59.3 & 104 \\
\hline 14 & 59 & F & - & OLB & 320 & 76.5 & 65.8 \\
\hline 15 & 75 & $\mathrm{M}$ & + & A & 462 & 60.0 & - \\
\hline 16 & 68 & $\mathrm{M}$ & + & A & 309 & 70.8 & 79.6 \\
\hline 17 & 70 & $\mathrm{M}$ & + & OLB & 447 & 83.6 & 71.7 \\
\hline 18 & 57 & $\mathrm{M}$ & + & OLB & 318 & 73.5 & 93.6 \\
\hline 19 & 67 & $\mathrm{M}$ & + & OLB & 471 & 82.5 & 73.9 \\
\hline
\end{tabular}

*: patients $1-7$ had IPF and patients $8-19 \mathrm{RA} ;{ }^{+}$: acute exacerbation. LDH: lactate dehydrogenase; $P \mathrm{a}, \mathrm{O}_{2}:$ arterial oxygen tension; VC: vital capacity; M: male; F: female; A: autopsy; OLB: open lung biopsy; +: smoker; -: nonsmoker.

"definite" RA. All of the autopsy cases had died owing to interstitial pneumonia with no evidence of bronchopneumonia or cardiac or other diseases.

The lung biopsy specimens were fixed in $10 \%$ neutral buffered formalin solution, cut into slices, embedded in paraffin and sectioned at $5 \mu \mathrm{m}$ for histological evaluation and immunchistochemical staining. Immunohistological staining was performed using the streptavidin/biotin/peroxidase complex method using anti-vimentin, anti-desmin and anti-S-100 protein (Dakopatts, Glostrup, Denmark), and $\alpha$-SMA (BioMaker, Rehovot, Israel) [6]. As to the characterization of these antisera, all antibodies gave positive staining in normal tissues as expected, and other primary antibodies expected to give negative results did so. As reported previously, it was established that myofibroblasts are vimentin-positive, $\alpha$-SMA-positive and desmin-negative, and that fibroblasts are only vimentin-positive, but $\alpha-S M A-$ and desmin-negative. In the present study, only $\alpha$-SMA-positive myofibroblasts were investigated. Up to three representative sections were selected from each case, and the pathological findings were divided into honeycomb, UIP and BOOP patterns for precise evaluation. Although quantitative assessment of the distribution of myofibroblasts and the number of S-100 protein-positive cells is difficult, each case was evaluated according to a 5-point scale: 4: many myofibroblastic foci or S-100 DCs; 3: small numbers of myofibroblastic foci or S-100 DCs; 2: some myofibroblastic foci or S-100 DCs in parts; 1: only focal myofibroblastic foci or few S-100 DCs; and 0: no myofibroblastic foci or S-100 DCs. Peripheral nerves, which were positive with anti-S-100 protein, and smooth muscle cells and perivascular areas (perivascular smooth muscle cells and pericytes) which were positive for $\alpha$-SMA, were excluded from the evaluation.

\section{Results}

Table 2 shows the results concerning $\alpha$-SMA-positive myofibroblasts in both IPF and RA-IP. In patients with chronic stage IPF, myofibroblasts were not usually observed (fig. 1), although they occasionally appeared in cases of acute exacerbation. In patients with RA-IP, myofibroblasts were observed in areas featuring honeycomb and BOOP patterns, and various foci of fibrosis were seen in all cases (fig. 2), and were particularly notable in areas of fibrin-deposition revealing a BOOP pattern (fig. 3). Statistical differences were detected between chronic IPF and RA-IP in the appearance of the myofibroblasts $(\mathrm{p}<0.001$ student's t-test $)$.

Table 2. - Distribution of myofibroblasts positive for $\alpha$ smooth muscle actin antibody in idiopathic pulmonary fibrosis (IPF) and rheumatoid arthritis (RA)

\begin{tabular}{lccc}
\hline \multirow{2}{*}{$\begin{array}{l}\text { Patient* } \\
\text { No. }\end{array}$} & \multicolumn{3}{c}{ Pathological pattern } \\
\cline { 2 - 4 } & Honeycomb & UIP & BOOP \\
\hline 1 & 3 & 3 & \\
2 & 3 & 4 & - \\
3 & 0 & 0 & - \\
4 & 3 & 1 & - \\
5 & 0 & 0 & - \\
6 & 0 & 0 & - \\
7 & - & 1 & - \\
8 & 3 & 3 & 4 \\
9 & 3 & 3 & 4 \\
10 & 3 & 3 & 3 \\
11 & - & 3 & - \\
12 & 1 & 3 & - \\
13 & 3 & 3 & - \\
14 & 3 & 3 & - \\
15 & 4 & 3 & 4 \\
16 & 3 & 3 & 4 \\
17 & - & 3 & - \\
18 & - & 1 & - \\
19 & 2 & 2 & - \\
\hline
\end{tabular}

*: patients 1-7 had IPF and patients 8-19 RA. UIP: usual interstitial pneumonia; BOOP: bronchiolitis obliterans-organizing pneumonia. 4: many positive foci; 3 : some positive foci; 2 : positive foci in parts; 1 : only focally positive foci; 0 : absent. 

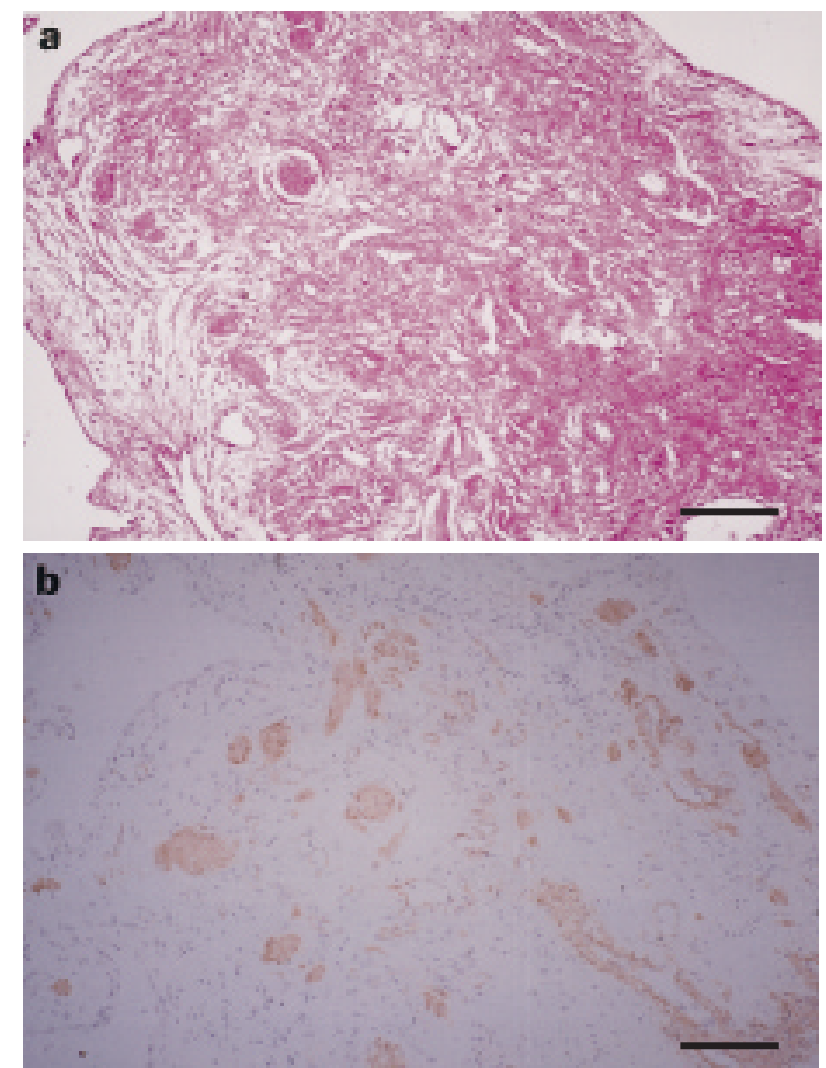

Fig. 1. - Fibrotic focus from patient 5 with usual interstitial pneumonia (a; haematoxylin and eosin stain) showing a positive reaction for $\alpha$ SMA actin antibody in small bundles of smooth muscle cells and perivascular areas (perivascular smooth muscle cells and pericytes) (b; streptavidin/biotin/peroxidase complex method). (Internal scale bars $=110 \mu \mathrm{m}$.)

The distribution of S-100 DCs in both IPF and RA-IP are shown in table 3. Few S-100 DCs were observed in areas of honeycombing and UIP in all cases of IPF (fig. 4). Those cells observed were small and had few cytoplasmic projections. In patients with RA-IP, on the other hand, a large numbers of S-100 DCs were observed, especially in areas characterized by BOOP (fig. 5a), some of which were detected within Masson bodies, and also tended to be present in UIP and honeycomb patterns. One of the RA-IP cases did not show S-100 DCs. This may be due to the mild pathological changes, including fibrosis, which characterized this case. The S-100 DCs in RA-IP were large and irregular in form with long projections, and morphologically more diverse than in those cases in which they were observed in IPF. Their nuclei were also often positive with S-100 protein antibody. The appearance of S-100 DCs very often occurred in the areas, where aggregated lymphocytes or lymph follicle-like structures were present (fig. 5b). Statistical differences here detected between chronic IPF and RA-IP groups with regard to the presence of S-100 DCs $(\mathrm{p}<0.05$ Student's t-test). No relationship was detected between smoking history and the presence of S-100 DCs.

\section{Discussion}

The prognosis in IPF is poor [1]. T cells, B cells, alveolar macrophages and proliferating type II alveolar
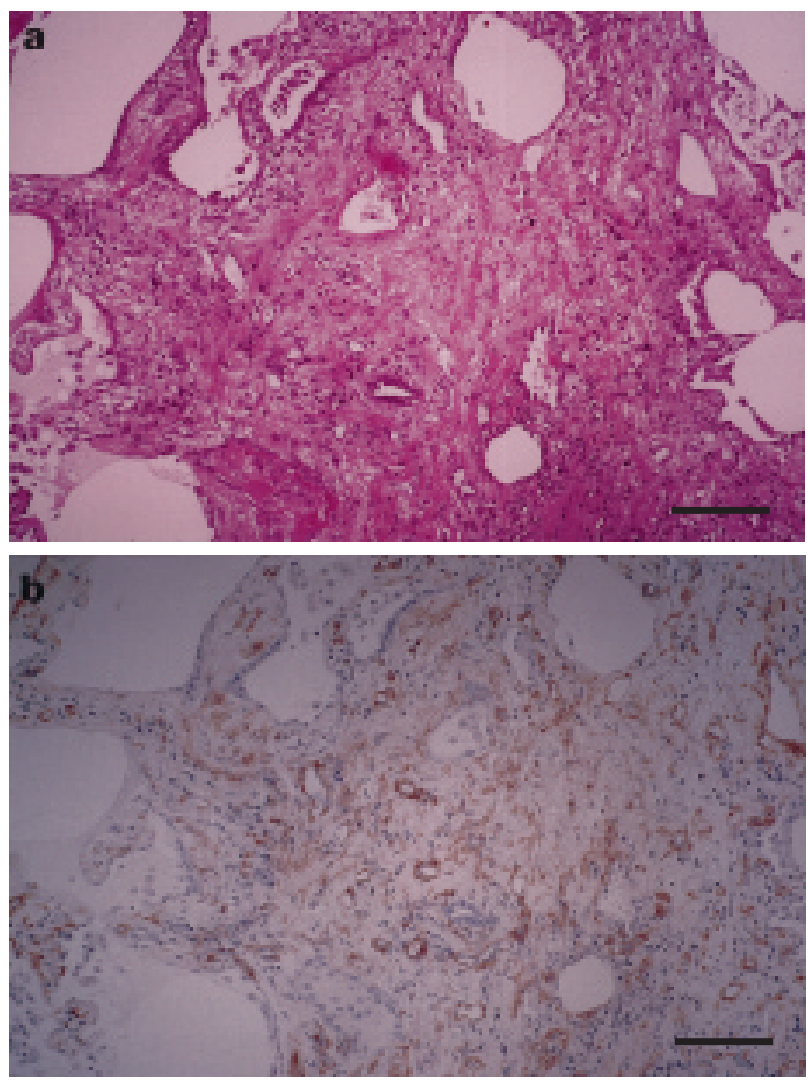

Fig. 2. - Fibrotic focus from patient 12 with rheumatoid arthritisassociated interstitial pneumonia (a; haematoxylin and eosin stain) demononstrating irregularly-arranged spindle myofibroblasts (b; streptavidin/ biotin/peroxidase complex method), which are positive for $\alpha$-smooth muscle actin antibody, in addition to perivascular smooth muscle cells and/ or pericytes. (Internal scale bars $=110 \mu \mathrm{m}$.)

epithelial cells are considered to play roles in the progression from chronic inflammation to pulmonary fibrosis [3, $11,12]$, although the mechanisms by which they do so are still controversial. In this process, fibroblasts are affected by many growth factors, and activated fibroblasts produce collagen $[11,12]$. In RA-IP, immunological mechanisms are considered to be involved, as also speculated in IPF. Therefore, whether or not IPF and RA-IP are the same pathological entity remains unresolved. It has been previously reported that there are two organizing processes in COP [6]. In this study, therefore, fibroblasts were evaluated in interstitial pneumonia of IPF and RAIP by means of immunological staining with both vimentin and $\alpha$-SMA antibodies.

The myofibroblast, a cell having ultrastructural features intermediate in form to those of fibroblasts and smooth muscle cells, was first described in granulation tissue [13]. Myofibroblasts vary in the types of contractile and intermediate filaments they express. They have been suggested to play a role in wound contraction and in the retractile phenomena observed during fibrotic diseases $[14,15]$. Skalli et al. [16] identified four types of fibroblast/myofibroblast which express: only vimentin (a cells); vimentin, $\alpha$-SMA and desmin (b cells); vimentin and $\alpha$ SMA (c cells); and vimentin and desmin (d cells). It has been reported that many myofibroblasts in both the Masson bodies of BOOP and the fibroblastic foci of UIP 

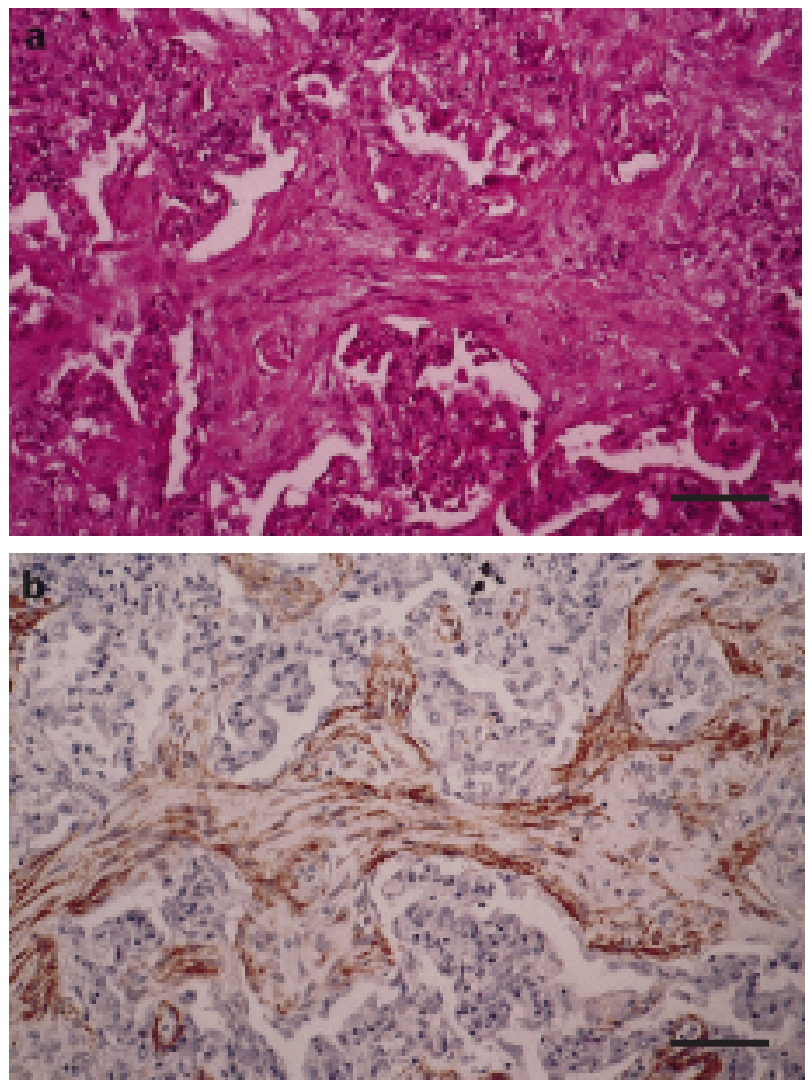

Fig. 3. - Intraluminal fibrosis from patient 8 with with rheumatoid arthritis-associated interstitial pneumonia revealing myofibroblastic cell proliferation positive for $\alpha$-smooth muscle actin: a) haematoxylin and eosin stain; and b) streptavidin/biotin/peroxidase complex method. (Internal scale bars $=55 \mu \mathrm{m}$.)

are of the $\mathrm{c}$ type [17]. Although $\alpha$-SMA-positive cells are present in IPF $[18,19]$, especially in acute exacerbation induced by unknown factors, as presented in this study, the present findings demonstrate that myofibroblasts are not observed in the chronic stages of IPF. Therefore, it might be suggested that myofibroblasts are involved early on and that the character of the myofibroblasts detected in IPF reflects its different stages. This suggests that active contraction of myofibroblasts plays a role in the remodelling of the lung in pulmonary fibrosis. Fibrosis in RAIP, on the other hand, is characterized by the appearance of myofibroblasts, in contrast to that in the chronic stage of IPF.

Little is known about the aetiology or pathogenesis of interstitial pneumonia. Alveolar macrophages produce mediators that are capable of stimulating inflammatory and reparative processes. Many of these are chemotactic factors and certain cytokines, termed fibrotic cytokines, directly trigger the proliferation of fibroblasts and/or stimulate the production of connective tissue. Transforming growth factor (TGF) is one of the well-documented fibrotic cytokines [20]. Broekelmann et al. [21] reported the expression of TGF- $\beta$ messenger ribonucleic acid (mRNA) in alveolar macrophages and in the foci containing the activated fibroblasts. As regards myofibroblasts, it was reported that subcutaneous administration of TGF- $\beta 1$ to rats resulted in the formation of a granulation tissue, in which $\alpha$-SMA-expressing myofibroblasts were particularly ab-
Table 3. - Distribution of cells positive for S-100 protein in idiopathic pulmonary fibrosis (IPF) and rheumatoid arthritis (RA)

\begin{tabular}{lccc}
\hline \multirow{2}{*}{$\begin{array}{l}\text { Patient* } \\
\text { No. }\end{array}$} & \multicolumn{3}{c}{ Pathological pattern } \\
\cline { 2 - 4 } & Honeycomb & UIP & BOOP \\
\hline 1 & 1 & 0 & - \\
2 & 0 & 1 & - \\
3 & 0 & 0 & - \\
4 & 0 & 0 & - \\
5 & 0 & 0 & - \\
6 & 0 & 0 & - \\
7 & - & 1 & - \\
8 & 3 & 4 & 4 \\
9 & 3 & 3 & 4 \\
10 & 1 & 3 & 3 \\
11 & - & 4 & - \\
12 & 1 & 1 & - \\
13 & 4 & 4 & - \\
14 & 4 & 3 & - \\
15 & 1 & 0 & 4 \\
16 & 1 & 0 & 3 \\
17 & - & 3 & - \\
18 & - & 0 & - \\
19 & 3 & 3 & - \\
\hline
\end{tabular}

*: patients 1-7 had IPF and patients 8-19 RA. UIP: usual interstitial pneumonia; BOOP: bronchiolitis obliterans-organizing pneumonia. 4: many positive cells; 3 : small numbers of positive cells; 2 : positive cells in parts; 1 : only focally positive cells; 0: absent.

undant [22], and that TGF- $\beta$ can stimulate collagen production by fibroblasts $[15,23]$. These results suggest that fibrosis in RA-IP may also be a result of myofibroblast proliferation induced by TGF- $\beta$. However, whether myofibroblasts observed in RA-IP and in acute exacerbation of IPF are the same or not must be further evaluated more precisely by using methods other than the present ones. Although the mechanism of myofibroblast proliferation remains to be clarified, the pathological profile of interstitial pneumonia does not appear to be identical in IPF and RA-IP.

Although both S-100 DCs and Langerhans' cells are positive for S-100 protein, they are different cell types. Langerhans' cells are usually present only in squamous epithelia, but S-100 DCs are detected in the dermis and

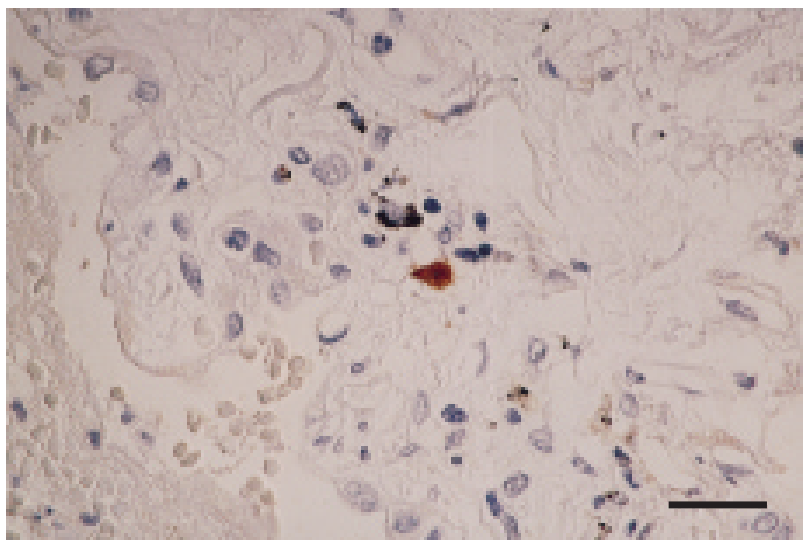

Fig. 4. - Small simplified S-100 dendritic cell from patient 6 with usual interstitial pneumonia. (Streptavidin/biotin/peroxidase complex method; internal scale bar $=30 \mu \mathrm{m}$.) 

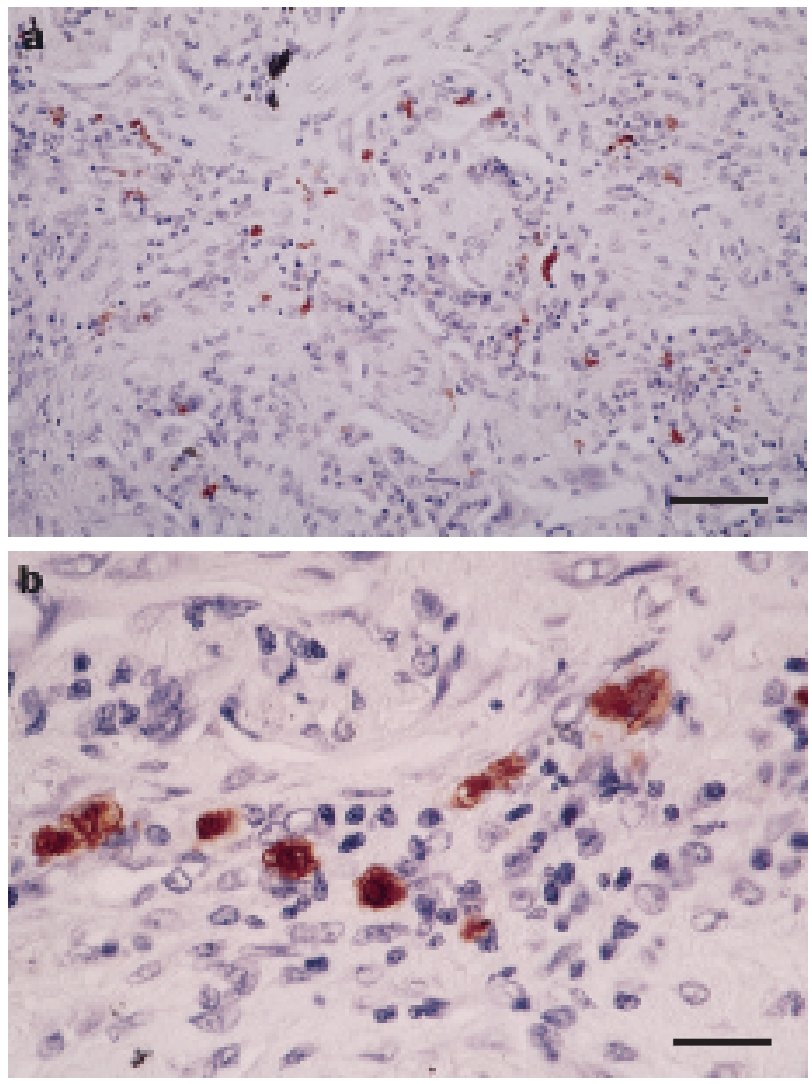

Fig. 5. - Many large irregularly shaped S-100 dendritic cells (a) detected from patient 8 with rheumatoid arthritis-associated interstitial pneumonia, frequently appearing near lymphoid cell aggregation (b). (Streptavidin/biotin/peroxidase complex method; internal scale bar=30 $\mu \mathrm{m}$.

various kinds of neoplastic and inflammatory lesions. WeBBer et al. [24] reported that many Langerhans' cells stained for S-100 protein were observed in eosinophilic granuloma of the lung but that few S-100 DCs were observed in UIP, honeycomb and eosinophilic pneumonia. However, there has not been a report of S-100 DCs in RA-IP. In the present study, few S-100 DCs were observed in all IPF cases, but various S-100 DCs appeared in various pathological areas of RA-IP, as shown in table 3 . The appearance of S-100 DCs was particularly notable in the five cases in which BOOP was present. The significance of this finding remains obscure. Immunocompetent cells are likely to be involved in RA, and the prognosis of various cancer patients was recently reported to be better if more S-100 DCs were detected in cancer tissue [25, 26]. Therefore, the demonstration of S-100 DCs may be a morphological manifestation of the antigen-presenting ability of some kinds of immune surveillance system. The finding that S-100 DCs appeared much more frequently in RA-IP than in IPF suggests that S-100 DCs may serve to differentiate the two diseases. However, these positive cells are often observed in other conditions involving nonspecific inflammation and so the usefulness of S-100 DCs may be limited to the differential diagnosis of UIP in IPF and UIP pattern in RA-IP.

The above evaluation of myofibroblast proliferation and the appearance of S-100 protein-positive dendritic cells suggests a possible means of differentiation between chro- nic idiopathic pulmonary fibrosis and rheumatoid arthritisassociated interstitial pneumonia. In the authors' opinion, the most important issue in interstitial pneumonia is to redefine the pathological characteristics and to establish a more advanced classification of UIP to be consistent in clinical diagnosis. It is possible to classify usual interstitial pneumonia in more detail according to differences in the nature of the proliferating cells, the types of infiltrating cell and the organizational character in the alveolar cavity, as performed in this study. Such classification is considered to be important for the future elucidation of the cause and pathological profile of interstitial pneumonia.

\begin{abstract}
Acknowledgements. The authors are grateful to S. Numoto, Kochi Municipal Hospital, Kochi, Japan for providing materials.
\end{abstract}

\section{References}

1. Crystal RG, Fulmer JR, Roberts WC, Moss ML, Line BR, Reynolds HY. Idiopathic pulmonary fibrosis: clinical, histologic, radiographic, physiologic, scintigraphic, cytologic, and biochemical aspects. Ann Inter Med 1976; 85: 769-788.

2. Carrington CB, Gaensler EA, Coutu RE, Fitzgerald MX, Gupta RG. Natural history and treated course of usual and desquamative interstitial pneumonia. N Eng J Med 1978; 298: 801-809.

3. Crystal RG, Bitterman PB, Rennard SI, Hance AJ, Keogh BA. Interstitial lung diseases of unknown cause: disorders characterized by chronic inflammation of the lower respiratory tract. $N$ Eng $J$ Med 1984; 310: 235-244.

4. Myers JL. NSIP, UIP and the ABC's of idiopathic interstitial pneumonias. Eur Respir J 1998; 12: 1003-1004.

5. Yousem SA, Colby TV, Carrington CB. Lung biopsy in rheumatoid arthritis. Am Rev Respir Dis 1985; 131: 770777.

6. Yoshinouchi T, Ohtsuki Y, Kubo K, Shikata Y. Clinicopathological study on two types of cryptogenic organizing pneumonitis. Respir Med 1995; 89: 271-278.

7. Moore BW. A soluble protein characteristic of the nervous system. Biochem Biophys Res Commun 1965; 19: 739-744.

8. Takahashi K, Isobe T, Ohtsuki Y, Sonobe H, Takeda I, Akagi T. Immunohistochemical localization and distribution of S-100 proteins in the human lymphoreticular system. Am J Pathol 1984; 116: 497-503.

9. Takahashi K, Isobe T, Ohtsuki Y, Sonobe H, Yamaguchi H, Akagi T. S-100 protein positive human T-lymphocyte. Am J Clin Pathol 1985; 83: 69-72.

10. Furukawa T, Watanabe S, Komada T, Sato Y, Shimosato Y, Suematsu K. T-zone histiocytes in adenocarcinoma of the lung in relation to postoperative prognosis. Cancer 1985; 56: 2651-2656.

11. Kovacs EJ, DiPietro LA. Fibrogenic cytokines and connective tissue production. FASEB $J$ 1994; 8: 854-861.

12. Cathcart MK, Emdur LI, Ahtiala-Stewart K, Ahmad M. Excessive helper T-cell function in patients with idiopathic pulmonary fibrosis: correlation with disease activity. Clin Immunol Immunopathol 1987; 43: 382-394.

13. Gabbiani G, Ryan GB, Majno G. Presence of modified fibroblasts in granulation tissue and their possible role in wound contraction. Experientia 1971; 27: 549-550. 
14. Darby I, Skalli O, Gabbiani G. $\alpha$-smooth muscle actin is transiently expressed by myofibroblasts during experimental wound healing. Lab Invest 1990; 63: 21-29.

15. Schmitt-Graff A, Desmouliere A, Gabbiani G. Heterogeneity of myofibroblast phenotypic features an example of fibro-blastic cell plasticity. Virchows Archiv 1994; 425: 3-24.

16. Skalli O, Suchurich W, Seemayer T, Lagace R, Montandon BP, Gabbiani G. Myofibroblasts from diverse pathological settings are heterogenous in their content of actin isoforms and intermediate filaments proteins. Lab Invest 1989; 60: 275-285.

17. Kuhn C, McDonald JA. The role of the myofibroblast in idiopathic pulmonary fibrosis. Am J Pathol 1991; 138: $1257-1265$.

18 Leslie K, King TE Jr, Low R. Smooth muscle actin is expressed by air space fibroblast-like cells in idiopathic pulmonary fibrosis and hypersensitivity pneumonitis. Chest 1991; 99: 47S-48S.

19. Kapanci Y, Gabbiani G. Contractile cells in pulmonary alveolar tissue. In: Crystal RG, West JB, Barnes PJ, Weibel ER, Eds. The Lung: Scientific Foundations. 2nd ed. Philadelphia, Lippincott-Raven, 1997, pp. 697-707.

20. Thorton SC, Pot SB, Walsh BJ, Penny R, Breit SN. Interaction of immune and connective tissue cells: the effects of lymphokines and monokines on fibroblast growth. J Leukocyte Biol 1990; 47: 312-320.

21. Broekelmann TJ, Limper AH, Colby TV, McDonald JA. Transforming growth factor $\beta 1$ is present at sites of extracellular matrix gene expression in human pulmonary fibrosis. Proc Natl Acad Sci USA 1991; 88: 66426646.

22. Desmouliere A, Geinoz A, Gabbiani F, Gabbiani G. Transforming growth factor- $\beta 1$ induces $\alpha$-smooth muscle actin expression in granulation tissue myofibroblasts and in quiescent and growing cultured fibroblasts. $J$ Cell Biol 1993; 122: 103-111.

23. Narayanan AS, Page RC, Swanson J. Collagen synthesis by human fibroblasts. Biochem J 1989; 260: 463-469.

24. Webber D, Tron V, Askin F, Churg A. S-100 staining in the diagnosis of eosinophilic granuloma of lung. Am J Clin Pathol 1985; 84: 447-453.

25. Ambe K, Mori M, Enjogi M. S-100 protein-positive dendritic cells in colorectal adenocarcinomas. Cancer 1989; 63: 496-503.

26. Nakajima T, Kodama T, Tsumuraya M, Shimosato Y, Kameya T. S-100 protein-positive Langerhans' cells in various human lung cancers, especially in peripheral adenocarcinomas. Virchows Arch A Pathol Anat Histopathol 1985; 407: 177-189. 